\title{
Yogmaya: Historical Reality in the Fictional Existence
}

\author{
Anupa Wagle
}

\begin{abstract}
The aim of this article is to analyze the novel Yogmaya to find out the balance between the fictional world presented in it and the history related to it. Written as a novel on the background of Rana Period in Nepal, my endeavour is to find out whether the novel is successful to portray the contemporary Nepalese society. In order to analyze the novel this study draws insight from new historicism that demands the equal weight for literary foreground and historical background. For this, the study is limited within some aspects of New Historical approach and fictional world related to social phenomena presented in the novel. Finally, this article includes the major finding of this study that the fictional foregrounding of the novel successfully portrays the contemporary social background of the concerned time and place. Free translation is used while citing texts from the novel since it is in Nepali.
\end{abstract}

Keywords: Realism, historicism, new historicism, evil customs, women movement.

\section{Yogmaya and the Nepalese History: An Introduction}

In the history of Nepal, Rana Regime is known as Dark Age as it lacked freedom, public sovereignty, and public literacy. It started from the rule of Jung Bahadur Rana in 1903 BS causing 'Kot Parwa' [Kot Massacre] to happen. From then Rana regime continued for 104 years. Many people sacrificed their lives while they revolted against that ruling system. Our history always remembers the contribution of four martyrs who belong to that age. Beyond those martyrs there were many who sacrificed their lives to establish the kingdom with justice; but Nepalese history always neglected them. Yogmaya is the writing of such a powerful but hidden history of the time.

Written by Nilam Karki Niharika, Yogmaya, is a novel drawing its background from the Rana Rule in Nepal. Published in 2074 BS, it is the Madan Prize winning novel which provides its focus for a lady figure known as 'Thulihajur' [The Eldest Sister] who even shakes the throne of the Rana Rulers by advocating against superstitions, evil customs and discriminations pervasive in the then society. Her efforts and contributions were challenging as well as rebellious. Written after about 80 years of her death, Yogmaya nicely portrays the contemporary scenario with the help of 'Thulihajur movement'. 
2 JODEM: Journal of Language and Literature, vol. 10, no. 1, issue 12, 2019/2076BS

\section{Problem, Objectives, Methodology and Limitation}

Literature is the mirror of the society as it portrays social, economic, educational, historical and cultural phenomenon of the time. It, in the form of fiction or non-fiction, includes different aspects of the society; later on that turns to be the history. Sometimes historical records does not include each and every minor detail of that aspect such as who invent the history, whose perspective is there to write it, and whether the writer is a commonor or the person in power. In this context, Yogmaya is a hidden history which is shadowed to be documented in the mainstream Nepalese history because our history books never mentioned the contributions of a lady-leader of the past, Thulihajur. On this background, this study tries to find how the novel represents the then social situation, Yogamaya's revolt and its New Historical writing. For this, the folloing research questions are set:

- How does the novel portray the then contemporary Nepalese society?

- How are the fictional foreground and historical background parallel to the formation of the Nepalese history?

The objective of the study is to portray the contemporary Nepalese society through the novel Yogmaya, and to focus on the missing history by interpreting it. For this the research questions are answered with the use of new historical perspective. Moreover, this study is limited within some aspects of New Historical approach and mainly the social aspect of the novel Yogmaya.

The term 'new historicism' was coined by the American critic Stephen Greenblatt whose book Renaissance Self-Fashioning from more to Shakespeare (1980) is usually taken as its advent. However, similar tendencies can be identified in work by various critics published during the 1970s. It denies privileging the literary foreground and a historical 'background'. It focuses for the equal weight of both literary text and non-literary texts. Similarly, American critic Louis Montrose defines it as a combined interest in 'the textuality of history, the historicity of texts'. According to Greenblatt, it is an intensified willingness to read all of the textual traces of the past with the attention traditionally conferred only on literary texts (Barry 166). This is a new look at the relation beween society, power and literature.

The trend looking at history from this perspective and using it in literature has recently started in Nepal, too. Traditional hisroians such as Baburam Acharya and Surya Bikram Gyawali are known as national historicians. They were influenced by the national, ethnic, cultural and historical unity and its influence can be found in their writings, too. Moreover, both of them tried to interpret Nepalese nationality as an well-organized form; and both of them were the explorers of unity among diversity (Gautam 164). These days, the alternatives to their perspective have been growing. 
In history and politics, great king Prithwinarayan Shan was regarded as the founding figure of unity. Likewise, in literature or in fine arts, Bhanubhakta Acharya got the glory for foundation of unity. In that age, there were many invaders or brave personalities; however, Shah was their leader; and so, he turned to be the hero by integrating many kingdoms. Similarly, in literature there were many poets, among whom Bhanubhakta Acharya strengthened Nepali language and opened the way to make it Nepalese lingua franca. Along with the passage of time, people were attentive for the integration of Nepal, then the word 'brave' was prioritized and turned as if it was synonymous for the great figures like Prithwinarayan Shah or Bhanubhakta Acharya which can be seen through the writing of Gyawali, too ( Gautam165). These were the attempts to write the single history of the nation that gives voice just to the mainstream thoughts.

On the contrary, in recent development in Nepali socio-political conext, unity is distracted and multiple voices are emerging. The harness of Shah and Acharya like figures are loosened and it is blamed that history was written from the perspective of winner or stronger personalities. It is also said that because of Shah, many ethnic groups are endangered and because of Acharya, the development of other languages was hampered. Those historical centers are decentered now and there is a big question in the greatness of Shah and Acharya (Gautam 166). This development has given a space for the growth of alternative perspectives to social discourses including lierary creations.

In the above mentioned context, Yogmaya is the historical portrait of the time and biography of a lady figure whose contribution for social reform of the age was shadowed due to centralized history of the historicians' perspective. For which New Historicism demands for the equal weight for literary foreground and historical background.

To know about literary foreground and historical background, it is crucial to discuss the connection among fiction, fact and truth. Fact and fiction both are old acquaintances and both are the derivatives of Latin word. Fact comes from 'facere'-to make or do. In the same way, fiction comes from 'fingere'-to make or shape (Scholes et al.121). In our ordinary understanding 'fact' is associated with reality and truth. On the contrary, fiction is consort with unreality and falsehood. Literally fact means for us 'a thing done' and fiction means 'a thing made'. We can find strange relation between fact and fiction. History is the place where both of these come together. The word 'history' contains a double meaning. On the one hand, it means 'things that have happened. On the other, it can refer 'a recorded version of the things that are supposed to have happened. It means both the event of the past and the story of these events. Therefore, fact, in order to survive must become fiction as these are not opposites but complementary to each other (122). These ideas and relaitons beween facts and fiction are interpreted in this aricle. 


\section{Yogmaya and Historical Context: A Review of Literature}

Many scholars have mentioned different views about Yogmaya. Michael Hutt mentions that in Nepal it is widely believed that in 1941 Yogmaya, a female religious ascetic, and 60 of her disciples drowned themselves in the Arun River. In many of her 'utterances' (vaani) preserved in a book that was effectively banned in Nepal for forty years, Yogmaya called upon the Rana government to establish a dharmarajya, a religious state. The mass suicide is now interpreted as an act of protest at the Rana's failure to meet this demand. However the event is not mentioned in any published history of Nepal (382-397). In the same way, Ratna Books in its website mentions that Yogmaya is based on Yogmaya's life and it includes the struggle for the end of every kind of discrimination in the society (ratnabook.com).

Similarly, for the overview of Yogmaya well-known newspaper The Kathmandu Post under the title "Karki Awarded Madan Puraskar for Yogmaya" mentions that Yogmaya is based on the life of female protagonist Yogmaya Neupane (1860-1941), a religious leader and woman rights activist born in Bhojpur. She fought against the autocratic Rana regime. Moreover, to provide the historical context for this novel, the views for Yogmaya Neupane by Basnet et al is also significant. They mention that the contribution of Yogmaya Neupane in Nepalese Women Movement is remarkable. She submitted the proposal of her 268 demands which mentioned women's right to the contemporary Rana ruler. Unfortunately the contemporary government denied her proposal and 68 women including her committed suicide in the Arun River (302). This fact shows the connection of fictional world and the historical context, too.

The above mentioned views show that the role of Yogmaya in Nepalese history is immense but the Standard Nepalese History did not mention it anywhere. For this the novel Yogmaya can take the equal weight to establish the history or foreground the history. For this regard, new historical study of the novel Yogmaya is necessary to throw light on the connection between historical reality and fictional creativity.

\section{Connecting Historical Reality and Fictional Creativity}

Thulihajur is the leading character of the novel Yogmaya. She happened to get married at the age of about seven with the unknown person named Ishwor Padhya Koirala from Dhodle. The marriage was not successful. Then she moved to Asam with a Kandel. After his death, she got married with the father of Nainakala. After giving birth to Nainakala, she realized the sin of remarriage and took the path of religion and came back to Simle, where she was born. Then she played a vital role to change the society through religious activities till her death.

The novel presents many customs of that time. One of them is the tradition of oiling the feet of husband and mother-in-law. It can be seen through the following lines of the text: 
didiko dubai godaamaa tel ghasera dhogen ani bhaanjiko paalo thyo....tulasaakaa baakaa godaamaa pani ghasidiera paanas nibhaaen. [After putting oil on both feet of my sister-in-law, I greeted her....I also did this to Tulasa's father and put off the light.']

It shows that there was the tradition of oiling elder's feet specially husband and mother-inlaw in husband's house by daughter-in-law. And it was the daily tradition of the then Nepalese society. When we go through the novel, we find many evil customs found in the society; and child marriage is one of them. This custom is shown through many characters of the novel; namely, Thulihajur, Nainakala, and Tulasa. Thulihajur got married at the age of seven when she even did not know what the marriage was. Her father, Shreelal Neupane, just to keep his promise, made her get married in a distance of nearly three days walk from his home. Her mother had also got married in her childhood. In the same way, the then Nepalese society was the victim of illiteracy because of which parents used to make their children get married before the menstruation of their daughter so as to open the door of heaven. This reality is reflected in this fictional world through these lines from the text:

\section{'katiki bhain ni bhaanji?'}

'saatki...'

'yatrai thi dhodlebaata koiraalaale janti lera aaudaa meri naatini' hajuraamaale bhaanjilaai musaardai bhannubho. [The old women asked how old my niece was. I replied she was seven. ... Then she said: my sister in law's age was exactly the same when Koirala had brought wedding procession from Dhodle]. $(45,55)$

The above mentioned first conversation takes place between Maya's sister and Tulasa's mother where Tulasa's mother is asking the age of Nainakala and Maya sister replies that she is seven years old. Similarly, the second conversation takes place between Tulasa's mother and one of the so called grandmother where remembering the day of Maya's marriage, pointing to Nainakala, she conforms that Maya had the same age like her daughter now at the time of her marriage. Similarly, the same evil custom is presented through these lines:

bidhawaa pahiranki aaphni chhorilaai sirdekhi paausamma niyaalera matira hernubho didile....ti nau das barsaki bhanjile kati bujhin kati bujhinan aaphni aamaakaa kuraa. [Sister-in-law looked thoroughly to her daughter's dressed up in widow clothes....That nine or ten years old niece either understood her mother's talk or not!] (143)

The above mentioned circumstance shows that Nainakala was about ten but turned to be widow within a year of her marriage. It also reflects that child marriage was pervasive in that society. In the same way, Tulasa is the next representative character of this custom which is presented through these lines: 
tulasaako pani bihe aantekaa ra bhanjiko pani bihe milna gaa'ko...(134)

'tulasi ra bhaanji dautarijastaa po rachhan. utraiutraa.' (45)

'The wedding of niece was fixed and going to fix Tulasa's, too. Both of them seems alike in age and size.'

The above mentioned lines show that both Tulasa and Nainakala were same in age that was about ten. The wedding date was fixed for one and in the process for the next. It proves that both of them got married at the very early age of their life or in other words, in childhood.

All these examples show that there was the deep rooted tradition of child marriage for many generations in that contemporary society. And Maya's parents, Maya, Nainakala and Tulasa all are the sufferers of such social malpractice.

Sati custom is one of the evil customs of the then Nepalese society in which wife had to burn together compulsorily at the death of her husband. This novel prominently deals with the era around 1986. However, sati custom was eliminated from Nepal in 1977 BS. Therefore, this custom is mentioned only in talking and gossips of women in the novel, which can be found through these lines:

yatro Nepal banaaune raajaa prithibinaaraayan re... tara unai raajaakaa raanilaai sati jaana rokne kohi bhaenan. Tee raajaakaa raaniharu sati gae re.... Paatan bhanne arko thyo re. Tyahaakaa malla raajaa mardaa ektis janaa sati gakaare. Raajaa ranabahaadur mardaa raani rajesworilaai jabarjasti sati pathaako kuraa nepaalaan najaanne ko holaa ['It was heard that there was nobody to stop to be the sati for the queens of Prithiwinarayan Shah. His queens happened to be sati. Similarly, thirty-one queens of the Malla King of Patan turned to be sati. And everyone knows Rajeswori was forcefully made sati at the death of King Ranabahadur.'] (161-162)

Similarly, the harsh reality of sati custom and people's attitude towards it is mentioned through these lines:

baanchera kyarnu? khasam marepachhi tinkaa joilaai bidhawaa bhanera helaa garchhan. Alachchhini bhanchhan. Poitokui bhanchhan. Arkaakaa bachan sunera uthdai, basdai apamaan sahera, kalankako tikaa laaera baanchna bhandaa khasamsagai jiundai jalera marnu niko thaanne pani the. Tyastaa durbachan sunnu bhandaa aaphai chitaasangai jalyo aananda bhanneharu pani the. Kuraa pani kastaakastaa bhane marepachhi pani khasamlaai sabai kuraa chahinchha re. Bhaandaa bartan ta bramhanalaai daan dindaa utaa swargamaa bhog garchhan re. Joi daasi pani uhan chaahine hundaa tinlaai khasam pugne thamma jiudai pathauna namilne hunda jalaaera sangai pathaakaa re. [What to do by living? After the death of the 
husband, people misbehave the widow by calling ominous and husband killer. There were some who thought it was better to burn with the dead body of husband than to live by hearing others' sharp words and mistreatment. Look at the issues! Husbands need everything after death, too. They get all those needed things through Brahmin but cannot grant widow to the Brahmin. Therefore, they burnt wife with their dead husband to be together as servant in heaven]. (164)

The above mentioned feeling expressed by an aged woman shows the bitter reality of the contemporary society where there was the tradition to burn women with their dead husband generally among Chhetri and Brahmam communities. They used to make their daughter married to aged man and burn them with the aged dead husband. But it was not only for aged one, too. However, some issues show that 'sati' was not the obligation which is presented through these lines: "Meri sauta bhane uhaansangai gai ma bhane jaana paaina [My co-wife burned with my husband but I couldn't]" (164). This context shows that to be sati was not compulsion to everyone though it was prevalent then.

The next historical reality the novel deals with is that of untouchability. Nepalese society is based on caste system from the ancient time. Primitively, these castes were determined according to the occupation. But, later on, these divisions of castes turned to be upper and lower castes. Moreover, some castes are categorized as untouched castes. Through the study of the novel, we find that the society found in it was also the victim of untouchability. It is presented through the following lines: "didile isaaraa garera ti janaanaalaai bolaaunubhayo....maathi thaapaa gaauntira ghar bhaa'ki eutile bhanin " tyo ta kamini..." [With gesture, sister-in-law called that women..."She is Kamini..." said a woman from Thapa Gaun]" (145). This context took place when people with Thulihajur were singing hymn and glorification of god in hermitage when a Dalit woman was listening to the hymns hiding behind the tree. Then Thulihajur called her to join them but one of the devotees of Thulihajur said she was Kamini (one of the untouched caste). Then she hesitates to involve her in their group. It shows that the contemporary Nepalese society was swallowed by evil custom known as untouchability.

The novel presents the society of Rana period in Nepal. Therefore, it shows the bitter reality that education was not for common people; though possible, it was not easy to get in Nepal. The possibility of women education was almost nil. Only two characters could read and write namely Prem Narayan and Dukhuna. Prem Narayan got education from Kashi and Dukhuna was helped by him to read and write.

The novel portrays the rebellion of a leading woman character, Thulihajur who was known as 'Bhaktini Mata'. If we analyze period of her movement, it seemed to happen before New Women Movement of the 1960s in the world history. From this history we can say that in 
Nepal women movement took place before the western countries. Moreover, being a woman Thulihajur's attempt was not only for women's redemption but for the whole the then contemporary society. It also proves that women's movement in Nepal was powerful than that of the west as she was able to shake the throne, too. Her rebellion and sacrifice, though in the form of religious activities, was for social liberation. Thulihajur's rebel against sati custom can be found through this expression from the novel:

Thulaa bhannele dherai bhandaa dherai joi bihe garne, baanchunjel moj garne ani tyo poi marepachhi sautaa- sautaamaa kalaha naparos bhanera pani jalaae. Arko kuraa bahubivahamaa angsa baandera chhutaaidinubhandaa baru jalaaidinu pani sajilo. Sati najaandaa aaphule aaphnaa khasamlaai maayaa nagareko thaharine hisaabko bujhaai pani bho. Yasaigari bujhae dharmabhiruharule ... dharmako naamamaa mati bhrasta paardai lagepachhi ke laagchha? [To use women as property, upper class people got many wives; and burnt them to stop the quarrel among co-wives after the death of husband. People understood that they did not love their husband if they did not be sati. In this way, the so called religious people interpreted.... What to do for those who destroyed their propensity in the name of religion.] (158)

It shows that Thulihajur disagreed with the sati custom and its understandings and misinterpretation.

Thulihajur's rebellion against untouchability can be seen through her activities of drinking water from the hand of Kainli Kamini and involving her into her group to sing the glory of god which can be found through these lines:

Didile bhannubho 'daraaunu pardaina, saara paani. Bhara kamandalu...'. Thado ghaanti gari dui chaar ghudki khaanu pani bho ... ra bhannubho 'yo bis baneko chhaina. Kasaile chhundaa amrit kasaile chhundaa bis banne hoina. [Sister-in-law ordered to bring water in kamandalu (water pot used by saints) and drank and said that it was not poison. People's touch has not made it poison or ambrosia.] (148)

This expression shows that being the daughter of Brahmin she challenged the society for untouchability by drinking water from a dalit woman. However, the contemporary society did not allow it to do. Further more, Thulihajur's rebel against discrimination based on cast can be seen through these lines:

Ma jaatpaat chhuwaachhut maathi rattibhar biswaas raakhdina. Haami sabai iswarkaa santaan haun ra haun haami sabai ekai jaati-maanav jaati. Yahaan sabai samaan chhaun. [I do not believe on caste system. We all are the creation of god and have a single caste as human being. We all are equal]. (146) 
The above expression shows that Thulihajur was the supporter of humanity and rebellious against discrimination based on caste system.

Yogmaya presents Thulihajur as a character whose voice was not only limited for a particular place or caste but for the whole humanity. Being born in Brahmin family, she rebelled against Brahmin who misinterpreted religion for their shake. It can be seen through the saying: "Hera, braahmanko chhoro bed padhchha, majastilaai bhed garchha. [See, the son of Brahmin reads Vedas and discriminates women like me]" (147). It shows that the then contemporary society believed that Vedas were only for Brahmins; so the society did not allow others to read it. But Thulihajur thought it was useless to follow religion if we did not treat people equally as religion never teaches us to discriminate people.

In the same way, her rebellion in the society can be found through this expression of Tulasa's father:

Aba gardaa gardaa brahmansanga jori khojne bhain didi ... puranko saangge nai bitholna maathi gaaun pugekire. Saashtraartha garne bhaeki re. Braahmanko kulamaa janmadaimaa braahman bhaidaina bhaninre. Jasle bramhabaare jaandachha uhi braahmanre! [Look! The sister started to argue with Brahmins. It is heard that she reached to destroy religious ceremony ( Purana) in the nearby village. She argued about religion that nobody could be Brahmin by birth rather must have the knowledge to be Brahmin]". (108)

In the above mentioned expression Tulasa's father is angry with his sister, Thulihajur, as she argued with Brahmins for many bad customs which religion compels people to follow. Not only Tulasa's father but the whole Brahmins in that community were resent towards her expression and activities. Being a female, Thulihajur rebelled against the superstitious society without fearing the result. Even today most of the Nepalese rural societies are victimized by many evil customs and it is difficult to illuminate it from the root even if $65 \%$ of the public are literate. For this, Thulihajur's activities or rebellion in that society about a hundred years ago is really praiseworthy and challenging, too.

In the novel Thulihajur's effort for the re-marriage of widow is challenging and praiseworthy in that contemporary society which was badly affected with superstitions and traditions. People were deprived of getting education. In such a condition, men were free to get re-marriage; however, women were not. Because of it still today we find many child-widows in our society. But Thulihajur's rebel for the re-marriage of widows can be seen through these lines: 
10 JODEM: Journal of Language and Literature, vol. 10, no. 1, issue 12, 2019/2076BS

Yo samaajlaai mero binti dharmako naammaa baalakhaimaa kanyaadaan kasaile nagari diun. Baalbidhuwaako laagi pariwaarle nai sa-sammaan bidurlaai jhain baato kholidiun. [I request this society that in the name of religion, nobody would get their children married in childhood. Like widower, their family had better manage for remarriage]. (242-243)

In this way, Thulihajur proves herself a rebellious character. Her rebellion can be seen in each and every aspect of society from child marriage, women education, untouchability, remarriage of widows along with religious matter. Because of all these matters, she became the target of the so called upper class people, Brahmins and even from Ranas. However, she was brave and determined character who even won the death through her hard work and penance.

This study finds these achievements related to the text based on the above mentioned problems and objectives. Yogmaya is the mirror of the then contemporary Nepalese society. It lively reflects the circumstances that can be heard from grandparents. The characters, places and time have made the novel as a written history of Nepalese society. To reach the present context, Nepalese society faced a lot of problems and difficulties either socially, politically or economically. However, it is only heard great figures' name as a reformer. Nepalese history shadowed many crucial characters of the past as history was written from the powerful's perspectives. The prominent character Thulihajur's role is not less prominent than four martyrs or Chandra Samser, who eliminated sati custom. However, the history of the powerful is known to all but not of Thulihajur who is one of the sufferered woman leaders of that hidden history. All these problems and situations related to her are presented through Yogmaya in the form of novel.

\section{Conclusion}

Yogmaya is a novel based on the life and activities of Yogmaya Neupane. The unity of fictional elements like characters, context, plot, dialogues, theme in total lively presents the history of Nepalese past by foregrounding fictional traces of every minute situation. It skillfully portrays the social realism of the age it has mentioned. It has its own fictional world which is the reflection of the history. Therefore, it is concluded that both historical background and fictional foreground are equally prominent to understand the hidden history of the concerned age as it is the spirit of New Historicism. Finally, this study will create the ground to change the perspective to look upon already existing historical records.

\section{Works Cited}

Barry, Peter. Beginning Theory: An Introductin to Literary and Cultural Theory. Viva Books, 2010. 
JODEM: Journal of Language and Literature, vol. 10, no. 1, issue 12, 2019/ 2076BS

Basnet, Ashok Kumar et al. Gender and Development. Sopan Masik, 2069 BS.

Gautam, Krishna. Uttar Aadhunik Jigyaasaa. [Postmodern Inquiry]. Bhrikuti Academic Publication, 2064 BS.

Hutt, Michael. "The Disappearance and Reappearance of Yogmaya". Contemporary South Asia, vol. 21, pp 382-397. https://www.researchgate.net/.../ 263344447

"Karki-awarded-madan-puraskar-for-yogmaya." Kathmandupost.ekantipur.com/ news/2018-08-28/.html

Karki, Nilam Niharika. Yogmaya. Sangrila Books, 2074 BS.

Scholes, Robert et al, editors. Elements of Literature. Oxford UP, 1997. 